\title{
Physiological and behavioral responses of feedlot sheep with and without access to artificial shade
}

\section{Respostas fisiológicas e comportamentais de ovinos mestiços confinados com e sem acesso ao sombreamento artificial}

\section{Lídia Mendes de Aquino Gontijo"; Diogo Alves da Costa Ferro ${ }^{2 *} ;$ Rafael Alves da Costa Ferro2; Bruna Paula Alves da Silva33; Klayto José Gonçalves dos Santos; Aracele Pinheiro Pales dos Santos²; Laís Gabrielly Freitas Lima4; Diogo da Silva Belizário ${ }^{1}$}

\section{Highlights}

Use of artificial shading in intensive sheep farming.

The sheep exhibited similar physiological and behavioral traits.

Shading can improve the welfare of sheep.

\begin{abstract}
Artificial shading is widely used to provide thermal comfort to animals and has been extensively researched due to its relationship with their welfare and performance. This study examines the physiological and behavioral traits of sheep in a feedlot system with and without access to shade. Twenty male Santa Inês $x$ Dorper crossbred sheep with an initial average weight of $25 \mathrm{~kg}$ were used in the experiment. The animals were kept in two collective stalls, one of which was equipped with a polypropylene mesh shade net with $80 \%$ light interception capacity. The experiment was conducted in the feedlot of the Fazenda Escola farm at UEG, São Luís de Montes Belos Campus, state of Goiás, Brazil. Environmental indices (ambient temperature, relative humidity, temperature-humidity index), respiratory rate (RR), rectal temperature (RT) and surface temperature (ST) were measured once weekly and behavioral assessments were performed one day after the physiological assessment, between $07 \mathrm{h00}$ and 19h00. The following behaviors were evaluated: feeding, rumination, rest/sleep, social, play and anomalous activities. There were no significant differences for the

1 Zootechnist, Master in Sustainable Rural Development, State University of Goiás, UEG, São Luís de Montes Belos, GO, Brazil. E-mail: lidiamendes22@gmail.com; diogo_tec@yahoo.com.br

2 Profs. Drs., Zootechnics and Veterinary Medicine Courses and Master in Animal Production and Forage, State University of Goiás, UEG, São Luís de Montes Belos, GO, Brazil. E-mail: diogo.ferro@ueg.br, rafael.ferro@ueg.br; klayto.santos@ueg.br; aracele.pales@ueg.br

3 Profa, Veterinary Medicine Course, União de Goyazes College, Faculty Union of Goyazes, FUG, Trindade, GO, Brazil. E-mail: brunaalveszoo@hotmail.com

${ }^{4}$ Zootechnist, Master in Zootechnics, UFG, Goiânia, GO, Brazil. E-mail: laisgabrielly.lima@hotmail.com

* Author for correspondence
\end{abstract}

Received: Nov. 14, 2020 - Approved: Feb. 25, 2021 
analyzed variables and treatments. Animals with access to shade had the following physiological results: RR - 75.06 mov. $\mathrm{min}^{-1}$; ST $-33.03^{\circ} \mathrm{C}$; and RT $-39.21^{\circ} \mathrm{C}$. Those without access to shade, in turn, showed the following indices: RR - 81.52 mov. $\mathrm{min}^{-1}$; ST $-33.45^{\circ} \mathrm{C}$; and RT $-39.43^{\circ} \mathrm{C}$. The evaluated behaviors did not differ significantly, averaging 226.11 and 225.44 min (feeding), 153.33 and 149.44 min (rumination), 341.39 and $339.72 \mathrm{~min}$ (rest/sleep) and 152.50 and $154.72 \mathrm{~min}$ (other activities) recorded in the sheep with and without access to shade, respectively. Despite the lack of differences between the analyzed responses, the animals with access to artificial shade showed greater comfort, welfare and quality of life.

Key words: Ambiance. Ethology. Lambs. Welfare.

\section{Resumo}

O sombreamento artificial é muito utilizado para proporcionar conforto térmico aos animais, e tem sido muito estudado em função da sua relação com o bem-estar e desempenho dos mesmos. Objetivou-se avaliar as características fisiológicas e comportamentais de ovinos em sistema de confinamento com e sem acesso a sombra. Foram avaliados 20 ovinos machos mestiços Santa Inês x Dorper com peso médio inicial de 25 $\mathrm{Kg}$, mantidos em duas baias coletivas, com implantação do sombrite de malha de polipropileno, $80 \%$ de interceptação luminosa em uma das baias. O experimento foi conduzido no confinamento da Fazenda Escola da UEG, Campus São Luís de Montes Belos, Goiás, Brasil. Avaliações ambientais, temperatura ambiente (TA), umidade relativa do ar (UR), índice de temperatura e umidade (ITU), frequência respiratória (FR) e de superfície (TS) foram realizadas uma vez por semana e avaliações de comportamento foram realizadas um dia após a avaliação fisiológica, entre 7h e 19h. Os comportamentos avaliados foram o alimentar, ruminação, descanso e sono, social, lúdico e anormal. Em relação aos resultados obtidos, não apresentaram diferença significativa em relação as variáveis e tratamentos analisados. Os animais com acesso a sombra apresentaram em relação à $\mathrm{FR}$, TS e TR, valores de $75,06 \mathrm{mov}$. $\mathrm{min}^{-1}, 33,03^{\circ} \mathrm{C}$ e $39,21^{\circ} \mathrm{C}$, respectivamente, enquanto os animais sem acesso ao sombreamento apresentaram $81,52 \mathrm{mov} \cdot \mathrm{min}^{-1}, 33,45^{\circ} \mathrm{C}$ de $\mathrm{TS}$ e $39,43^{\circ} \mathrm{C}$ de TC. Os comportamentos avaliados não diferiram significativamente, com médias em minutos para os comportamentos alimentar de 226,11 e 225,44, ruminação de 153,33 e 149,44, descanso e sono de 341,39 e 339,72 e outras atividades de 152,50 e 154,72, para os animais com e sem acesso ao sombreamento, respectivamente. Apesar de não observar diferenças entre as respostas analisadas, pode-se observar um maior conforto, bem-estar e qualidade de vida para os animais com acesso ao sombreamento artificial.

Palavras-chave: Ambiência. Bem-estar. Cordeiros. Etologia.

\section{Introduction}

Animals respond in production
according to their satisfaction or
dissatisfaction with the environment; hence
the importance of studying the environment
when working with animal behavior, since the
intakes of water and dry matter, as well as
production performance, are directly related

to the climate and to animal welfare (Ferreira, Estrada, Thiébaut, \& Granados, 2011).

Situations of critical temperatures and relative humidity above the limits call for strategies that provide environmental comfort. Natural or artificial shading is an efficient and practical technology in that it mitigates the effects of direct solar radiation at the most 
critical times of the day (C. B. Lima, Costa, Nascimento, \& Lima, 2014).

To assess the adaptive capacity or stress state of an animal in the production environment, some indicators must be used. These consist of physiological, behavioral, environmental and productive parameters, which should agree with bioclimatic indices, stress and the fulfillment of the "five freedoms" of animal welfare (Rebouças et al., 2018).

Stress can be due to a reaction of the organism to aggressive factors in the environment. However, severe stress results in learned withdrawal, i.e., the animal learns that it will not manage to adapt to the environment, no longer attempting to adjust to the system. This situation causes damage to animals, such as impairment of the immune system, rendering them fragile and susceptible to diseases; delayed productivity; and the presence of anomalous behaviors (L. R. Lima \& Barbosa, 2013).

Animals directly subjected to solar radiation perform thermoregulatory efforts in an attempt to dissipate heat. In doing so, they respond in various ways to the thermal environment, e.g., by increasing their respiratory rate (RR), body temperature and rectal temperature (RT). In addition, they also modify their behavior, seeking shaded places in the hotter times of the day and reducing their search for food in the trough as well as grazing time.

Sheep can exhibit anomalous behaviors, which negatively influence their production performance. These behaviors are the result of an inability to adapt to the environment, for reasons considered stressful. Calviello, Titto, Amadeu and Titto (2013) stated that understanding the environmental and climatic conditions of the region where the sheep will be farmed and the natural behavior of the species is the principle of successful animal welfare, which is a growing concern of the highly demanding current market.

An example of anomalous behaviors are stereotypies, that is, repetitive behaviors, the acts of pulling wool, chewing wood chips from fences or walls, mounting animals of the same sex, ingesting soil and excessively licking body parts. To prevent animals from triggering stereotypies, care related to environmental comfort, food and handling and, above all, ethical respect in the production space are necessary (Rebouças et al., 2018).

Behavioral, climatic and physiological observations are important tools for the production efficiency and welfare of animals. In this scenario, the present study investigates the influence of artificial shading on climatic variables and on physiological and behavioral responses of crossbred sheep raised in an intensive production system.

\section{Material and Methods}

The experiment was developed in the Feedlot of the Fazenda Escola farm of the State University of Goiás, located on the São Luís de Montes Belos Campus, state of Goiás, Brazil, (16 $\left.31^{\circ} 20^{\prime \prime} \mathrm{S}, 50^{\circ} 22^{\prime} 48^{\prime \prime} \mathrm{W}\right)$. The experimental period was 70 days, of which the first 14 days were used for the animals to acclimate to the experimental conditions. According to the Köppen classification, the climate of the region is an Aw type (tropical with a dry period), with defined dry (May to October) and rainy (November to April) seasons (DBCity, 2021). Average minimum and maximum temperatures in the region are 20 and $31^{\circ} \mathrm{C}$, 
respectively, and average precipitation is 119 $\mathrm{mm}$.

The project was authorized by the Ethics Committee on Animal Use (CEUA) (approval no. 001/2019). The experiment involved 20 male, uncastrated Santa Inês $\times$ Dorper crossbred sheep with an average initial age of four months, average initial weight of 25 $\pm 5.48 \mathrm{~kg}$ and final weight of $35.18 \pm 7.10 \mathrm{~kg}$.

All animals were initially weighed, dewormed and identified by collars with numeric sections. They were kept in an intensive rearing system, where they were randomly distributed into two collective stalls, each containing 10 sheep.

Each stall was $12.2 \mathrm{~m}$ wide $\times 14.1 \mathrm{~m}$ long, totaling $172.02 \mathrm{~m}^{2}$, with $17.20 \mathrm{~m}^{2}$ per animal. One of the stalls was equipped with a black synthetic polypropylene mesh net shade $3 \mathrm{~m}$ wide $\times 8.5 \mathrm{~m}$ long $\left(25.5 \mathrm{~m}^{2}\right)$, with $80 \%$ light interception capacity, in the NorthSouth direction. The shading system provided $2.5 \mathrm{~m}^{2}$ of shade per animal, whereas the other stall remained unshaded.
The two treatment groups (with and without access to shade) received the same dietary management, which consisted of a concentrate with $15 \% \mathrm{CP}$, based on ground maize, soybean meal, urea and a vitaminmineral mixture, at the rate of $1.4 \% \mathrm{LW}$, on a DM basis. In the first seven days, the animals received the concentrate without urea, termed 'concentrate 1' (Table 1); in the second week, urea was included in the diet, characterized as 'concentrate 2'. The feed supply (DM basis) was adjusted according to the animal LW (\%). This adjustment was made with caution due to refusals, which were weighed daily in the morning, before the first treatment of the day, aiming at up to $5 \%$ orts.

The roughage, which was based on sorghum silage, was provided at the initial rate of $2.0 \% \mathrm{LW}$ (DM basis) in troughs within the stalls, together with the concentrate, four times daily (07h00, 10h00, 13h00 and 16h00). Water was available ad libitum, in a brick drinker. The sorghum silage contained $32.0 \%$ DM, 8.3\% CP, 68.4\% TDN, 65.3\% NDF, 48.0\% ADF and $1.7 \% \mathrm{EE}$.

Table 1

Percentage inclusion of each ingredient in the sheep concentrate, divided into concentrates 1 and 2 , according to the adaptation of the animals to the dietary management

\begin{tabular}{|ccc|}
\hline & Concentrate 1 & Concentrate 2 \\
\cline { 2 - 3 } Ingredient & $\%$ & $\%$ \\
\hline Ground maize & 55.5 & 72.5 \\
\hline Roasted soybean meal & 38.0 & 22.5 \\
\hline Vitamin-mineral mix & 6.5 & 4.0 \\
\hline Livestock urea & 0 & 1 \\
\hline TOTAL & 100 & 100 \\
\hline
\end{tabular}


To monitor environmental variables such as relative humidity (RH), dry-bulb temperature (DBT) and wet-bulb temperature (WBT), a psychrometer was used. The device was set to record the respective variables at $07 \mathrm{hO0}, 11 \mathrm{h00}, 15 \mathrm{hO0}$ and 19h00, in the shade and in the sun, twice weekly throughout the experimental period. Afterward, the temperature-humidity index (THI) was calculated using the following formula, as proposed by Thom (1958): THI: DBT + 0.36 * WBT + 41.5.

Physiological variables were evaluated on the same day of the week as the environmental variables, at 07h00 $11 \mathrm{~h} 00,15 \mathrm{hO0}$ and 19h00. The surface temperature of the pelage (ST) was measured in the very feedlot pen, using a digital infrared thermometer that was directed at a distance of one meter from the body of the animals, on the right side, in the regions of the neck, flank and testicles. The means were subsequently determined.

Respiratory rate (RR) was measured at the experiment site, by counting the movements in the flank region, on the right side of the animals, for $15 \mathrm{~s}$. The value was then multiplied by four, resulting in the number of movements performed by each animal per minute (mov. $\mathrm{min}^{-1}$ ). Six assessments of ST and RR were performed throughout during the experimental period.

For the measurement of RT, the animals were restrained on a mobile scale for weighing lambs. Rectal temperature was measured by inserting a digital clinical thermometer directly into the rectum of the animals so that the bulb was in contact with the mucosa for two minutes. Then, the temperature was read. This variable was collected on five occasions during the experiment, at 15-day intervals, in the morning, between 07h30 and 09h00.

Behavioral assessments were carried out once weekly, one day after the measurement of physiological variables. The sheep were observed for 12 consecutive hours, starting at 07h00 and ending at $19 \mathrm{h00}$. The interval between visual observations was $15 \mathrm{~min}$. The following behaviors were analyzed: feeding, rumination, rest/sleep, and other activities that included social behavior, body care, play, locomotion and anomalous activities. Six evaluations were carried out throughout the experiment. Environmental variables were also measured, along with behavioral assessments, at 07h00, 11h00, $14 \mathrm{~h} 00$ and $19 \mathrm{ho0}$.

The behavioral assessments were performed visually, by previously trained evaluators who were divided into pairs for the evaluation of each lot. The evaluators switched places every six hours and were positioned strategically so as not to disturb the animals or interfere with the environment. Digital watches were used to measure the time expended in each activity.

The experiment was laid out in a completely randomized design with two treatments (with and without access to artificial shade) and ten replicates. For the environmental, physiological and behavioral variables, an F-test of analysis of variance was performed at the $5 \%$ significance level for mean comparison, using $\mathrm{R}$ statistical software version 2.15.2. 


\section{Results and Discussion}

The air temperature (AT) during the experimental period was on average $29.34{ }^{\circ} \mathrm{C}$ in the shaded and $30.89{ }^{\circ} \mathrm{C}$ in the unshaded environment (Table 2), which did not vary statistically between treatments. Eustáquio
(2011) worked with the temperatures of 10 , $15,20,25,30,35$ and $40^{\circ} \mathrm{C}$, using a bioclimatic chamber, and found better physiological responses in Santa Inês sheep at $30^{\circ} \mathrm{C}$, which suggests that the AT in the present study was in favor of the thermal comfort of the animals.

\section{Table 2}

Temperature (T), relative humidity (RH) and temperature-humidity index (THI) in the sheep feedlot, with and without shade

\begin{tabular}{ccccccc} 
Environmental variable & \multicolumn{2}{c}{ Shade } & \multirow{2}{*}{$\mathrm{p}^{1}$} & CV (\%) & \multirow{2}{*}{ SD $^{3}$} \\
\cline { 2 - 3 } & Access & No access & & & \\
\hline $\mathrm{T}\left({ }^{\circ} \mathrm{C}\right)$ & 29.34 & 30.89 & 0.2487 & 20.91 & 6.30 \\
$\mathrm{RH}(\%)$ & 43.32 & 42.11 & 0.7658 & 44.95 & 19.20 \\
$\mathrm{THI}$ & 77.94 & 79.67 & 0.2587 & 9.06 & 7.14
\end{tabular}

${ }^{1}$ Probability value of the F-test of analysis of variance. ${ }^{2}$ Coefficient of experimental variation. ${ }^{3}$ Standard deviation.

Relative humidity directly influences the ability of an animal to tolerate the thermal environment, i.e., its heat balance (Voltolini, 2011). In this study, $\mathrm{RH}$ ranged from 42.11 to $43.32 \%$ in the environments without and with shade, respectively, with no statistical difference occurring between them. These values are within the ideal range for sheep, which is 40 to $70 \%$.

The THI values also did not differ statistically, averaging 77.45 in the shaded environment and 79.67 in the environment without shade. Baêta and Sousa (2010) stated that $\mathrm{THI} \leq 70$; from 71 to 78 ; from 79 to 83; or $>83$ represent normal, critical, danger, and emergency conditions, respectively.

Seixas, Melo, Tanure, Peripolli and Mcmanus (2017) consider $\mathrm{THI}<74$ as absence of stress. Thus, the THI values in the present study can be considered critical and dangerous situations for the environmental comfort of ruminants, which may have caused evidence of thermal discomfort for the sheep.

Results for RR (Table 3) did not differ between the two treatments, but were above normal for these animals. Respiratory rate was 75.05 mov. $\mathrm{min}^{-1}$ in the animals with access to shade and 81.52 mov. $\mathrm{min}^{-1}$ in those in the unshaded environment. These results demonstrate the responses of sheep in the attempt to adapt to environmental conditions when faced with high THI (Table 3) (77.94 and 79.67 in the shade and sun, respectively). Respiratory activity is important to prevent the animals from reaching a state of hyperthermia, which explains the altered values in both treatment groups. 


\section{Table 3}

Surface temperature (ST), respiratory rate (RR), and rectal temperature (RT) of feedlot sheep, with and without shade

\begin{tabular}{|c|c|c|c|c|c|}
\hline \multirow{2}{*}{ Environmental variable } & \multicolumn{2}{|c|}{ Shade } & \multirow{2}{*}{$p^{1}$} & \multirow{2}{*}{$\mathrm{CV}(\%)^{2}$} & \multirow{2}{*}{$\mathrm{SD}^{3}$} \\
\hline & Access & No access & & & \\
\hline ST $\left({ }^{\circ} \mathrm{C}\right)$ & 33.03 & 33.45 & 0.6460 & 7.32 & 2.43 \\
\hline RR (mov. $\min ^{-1}$ ) & 75.06 & 81.52 & 0.0741 & 25.41 & 19.90 \\
\hline $\mathrm{RT}\left({ }^{\circ} \mathrm{C}\right)$ & 39.21 & 39.43 & 0.2304 & 2.31 & 0.91 \\
\hline
\end{tabular}

${ }^{1}$ Probability value of the F-test of analysis of variance. ${ }^{2}$ Coefficient of experimental variation. ${ }^{3}$ Standard deviation.

Animals use their thermoregulatory mechanisms as a response to changes in AT, losing heat due to increased RR and sweating (Silva, Sousa, Santos, Marques, \& Torreão, 2013). Oliveira et al. (2013) found lower RR values in an experiment that demonstrated that the availability of shade influenced the RR of Santa Inês sheep in both the cold and hot seasons of the year. In their study, during the cold season, the average RR in the lambs with and without access to shade were 30.24 and 36.83 mov. $\mathrm{min}^{-1}$, respectively. In the hot period of the year, in turn, the respective means were

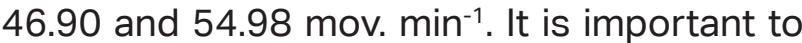
note that the higher RR values are outside the normal range for sheep.

According to Silanikove (2000), in small ruminants, RR lower than 40 mov. min-1 are indicative of normality or no stress; from 40 to 60 mov. min $^{-1}$, low stress; 60 to 80 mov. min $^{-1}$ medium-high stress; 80 to 120 mov. $\mathrm{min}^{-1}$, high stress; and 120 mov. min $^{-1}$ or more, severe stress. The present results for RR indicate medium-high stress in the animals granted the benefit of shade and high stress in those without it, demonstrating that the sheep were somewhat stressed in some moments of the day and made use of mechanisms to avoid hyperthermia.
Surface temperature is influenced by AT due to the animal physiology, whereby vasodilation and sweating are used during the body heat dissipation process (Eustáquio et al., 2011). This variable did not differ significantly, averaging 33.03 and $33.45^{\circ} \mathrm{C}$ in the lambs with and without access to shade, respectively (Table 3 ), both being within the appropriate range for sheep. If we consider that body temperature should be kept at the basal limit near $39.1^{\circ} \mathrm{C}$ (Luz et al., 2014), the Santa Inês $\times$ Dorper crossbred sheep were able to lose the heat necessary to preserve normal ST, maintaining homeothermy.

Oliveira et al. (2013) examined the skin ST of Santa Inês sheep with and without access to artificial shade and found values that ranged from 32.51 to $38.46{ }^{\circ} \mathrm{C}$. The authors reported that prolonged moments of high ST interfere with heat dissipation in the animal in a sensitive manner, requiring the use of perspiration and airways for it to lose heat.

Eustáquio et al. (2011) found that at ambient temperatures greater than $30{ }^{\circ} \mathrm{C}$, there was an increase in the ST of the pelt of Santa Inês lambs, which ranged between 32 and $40{ }^{\circ} \mathrm{C}$. The state of severe stress induces an increase in blood flow from the central 
to the peripheral part of the skin, causing it to change the heat flow and consequently increasing ST.

As in the study of Fabino, Miyagi, Brainer, Lima and Rebouças (2018), the RT values found in the current experiment did not differ statistically during the 70 days of confinement (Table 3). According to said researchers, the observed values are within the range from 38.5 to $40{ }^{\circ} \mathrm{C}$ considered ideal for healthy sheep, as the animals will be able to express behaviors, appetite and reactions in daily life.

Eustáquio et al. (2011) observed a significant variation $(\mathrm{P}<0.01)$ in $\mathrm{RT}$ as a function of ambient temperature, stating that RT changed at temperatures above $25{ }^{\circ} \mathrm{C}$, remaining between 38.5 to $39.5^{\circ} \mathrm{C}$.

Macías-Cruz et al. (2018) analyzed the thermoregulatory responses of RR and RT in sheep for four months and observed statistically significant differences $(P<0.05)$ for both variables in August, as compared with the other evaluated months. Rectal temperature decreased from 38.6 to $38.3^{\circ} \mathrm{C}$ in the night period, between midnight and noon, and rose from 38.7 to $39.5{ }^{\circ} \mathrm{C}$ during the afternoon, which are similar results to those found in this study in the same month. Respiratory rate remained altered in the month of August, averaging 80, 40 and 80 and $>120$ mov. $\mathrm{min}^{-1}$ at 00h00, 6h00, $12 \mathrm{hO0}$ and 18h00, respectively, which are higher values than those found in the present study.

Feedlot animals perform the daily activities of feed and water consumption, leisure, social behavior and rumination, and these are the main behaviors researched and analyzed in terms of behavioral parameters of ruminants. The distributions and frequency of behaviors may change throughout the day, depending on the momentary needs, or for survival in the face of extrinsic factors of the production environment which may or may not be interfered with by the human being. In this study, there was no significant difference in the behaviors performed by the sheep during the evaluation days and between treatments (Table 4).

\section{Table 4}

Average duration (in min) of behavioral activities performed by feedlot sheep with and without access to shade

\begin{tabular}{|cccccc}
\hline \multirow{2}{*}{ Behavior } & \multicolumn{2}{c}{ Shade } & \multirow{2}{*}{$\mathrm{p}^{1}$} & CV (\%) $)^{2}$ & SD $^{3}$ \\
\cline { 2 - 3 } & Access & No access & & & \\
\hline Feeding & 226.11 & 225.56 & 0.9579 & 21.57 & 48.71 \\
\hline Rumination & 153.33 & 149.44 & 0.6172 & 26.17 & 39.62 \\
\hline Rest and sleep & 341.39 & 339.72 & 0.8894 & 19.08 & 64.96 \\
\hline Other activities & 152.50 & 154.72 & 0.8068 & 31.49 & 48.37 \\
\hline
\end{tabular}

${ }^{1}$ Probability value of the F-test of analysis of variance. ${ }^{2}$ Coefficient of experimental variation. ${ }^{3}$ Standard deviation. 
The most performed behavior was rest/ sleep, followed by feeding and other activities in the unshaded environment, and rumination in the shaded environment. Marques et al. (2012) evaluated the feeding behavior of Santa Inês sheep and observed that in $24 \mathrm{~h}$ in an extensive rearing system, the lambs ate

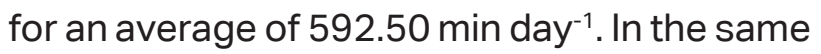
study, the average rumination time was 404 min day ${ }^{-1}$, idle time was 38 min day $^{-1}$ and other

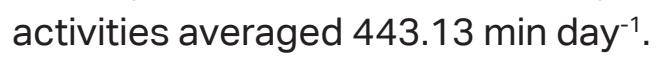

Ferreira et al. (2011) analyzed the behavior of sheep for 10 days and observed that the animals that received shade dedicated $73 \mathrm{~h}$ to grazing, whereas those that did not, expended $66 \mathrm{~h}$ feeding. The animals with access to shade showed less variation in their feeding behavior and lower RT, exhibiting less heat stress than those kept in the sun. This explains the present findings, where despite the lack of significant differences, the animals with access to shade performed more of the feeding, rest/sleep and rumination behaviors than those kept in full sun.

According to Voltolini (2011), it is normal for small ruminants to sleep during nighttime, whereas the daytime is intended for feeding, always at the fresher times of the day. On the other hand, in hot climates, sheep replace the feeding period with an increase in the duration of rest/sleep and idle activities. Thus, when shade is available, the animal uses the resource to remain adaptable to the climatic environment.

Manno etal.(2018) observed significant differences in the behavior of Santa Inês sheep in response to the influence of temperature and $\mathrm{RH}$, which showed maladjustments in their grazing behavior and increased idleness.

The absence of significant differences between the analyzed behaviors is explained by the fact that ambient temperature did not exceed the upper critical temperature for small ruminants in either treatment. According to Nobre, Souza, Marques and Batista (2013), sheep manage to preserve their body temperature stable in environments with minimum and maximum ambient temperatures of 5 and $45^{\circ} \mathrm{C}$, respectively.

Sheep are extremely social animals. In this study, although the data were not significant (Table 5), the sheep with access to shade expended more time in social behavior. Shading is the greatest influence for these animals to have social interaction, because they spend more time resting.

\section{Table 5}

Average of other behaviors (in min) performed by feedlot sheep with and without access to shade

\begin{tabular}{|c|c|c|c|c|c|}
\hline \multirow{2}{*}{$\begin{array}{l}\text { Behaviors termed "other } \\
\text { activities" }\end{array}$} & \multicolumn{2}{|c|}{ Shade } & \multirow{2}{*}{$\mathrm{p}^{1}$} & \multirow{2}{*}{ CV $(\%)^{2}$} & \multirow{2}{*}{$\mathrm{SD}^{3}$} \\
\hline & Access & No access & & & \\
\hline Social & 63.61 & 53.33 & 0.0760 & 21.69 & 12.68 \\
\hline Body care & 15.00 & 10.83 & 0.1573 & 25.98 & 3.36 \\
\hline Playful & 20.00 & 24.44 & 0.2112 & 20.74 & 4.61 \\
\hline Anomalous & 2.22 & 3.89 & 0.3189 & 24.62 & 0.75 \\
\hline Locomotion & 51.67 & 62.22 & 0.1716 & 27.58 & 15.70 \\
\hline
\end{tabular}

${ }^{1}$ Probability value of the F-test of analysis of variance. ${ }^{2}$ Coefficient of experimental variation. ${ }^{3}$ Standard deviation. 
Voltolini (2011) stated that anomalous behaviors in animals imply a lack of welfare related to motivational problems, which can be momentary or long-lasting, in an effort to control the environment. Rebouças et al. (2018) commented that trampling, pulling wool, ingesting feces, chewing bars or walls of the facility or excessive fighting with other animals in the group are stereotypies. The anomalous behaviors observed in the present study were sodomy, lignophagia and geophagia.

According to Malafaia, Barbosa, Tokarnia and Oliveira (2011), sodomy is the act of an animal mounting another of the same sex, with the dominant one typically jump over the other, causing damage to the hooves, carcass injuries, as well as reduced performance. Lignophagia is the act of gnawing and ingesting wood chips off walls of cubicles or fences. In some animals, this behavior causes lesions in the gums to the point of bleeding and generating problems such as abomasal obstruction, which may be due to environmental stress and also due to dietary fiber deficiency. Lastly, geophagia corresponds to the ingestion of soil, which causes problems in the abomasum.

\section{Conclusions}

There were no significant changes in the analyzed physiological and behavioral traits, between the treatments with and without shade.

\section{Acknowledgments}

The authors thank the State University of Goiás, their advisors, professors and academic trainees of the project for their support and encouragement during the research; the Board of Directors at UEG, São Luís de Montes Belos Campus, for the support in the execution of the project; and FAPEG, for the financial assistance provided as a fellowship grant.

\section{References}

Baêta, F. C., \& Souza, C. F. (2010). Ambiência em edificações rurais: conforto animal ( $2 a$ ed.). Viçosa, MG: UFV.

Calviello, R. F., Titto, C. G., Amadeu, C. C. B., \& Titto, E. A. L. (2013). Avaliação do comportamento de ovelhas em pastejo durante 24 horas. Revista Brasileira de Zoociência, 15(1,2,3), 139-145.

Db-City (2021). São Luís de Montes Belos. Recuperado de https://pt.db-city.com/ Brasil--Goi\%C3\%A1s--S\%C3\%A3oLu\%C3\%ADs-de-Montes-Belos

Eustáquio, A., Fo., Teodoro, S. M., Chaves, M. A., Santos, P. E. F., Silva, M. W. R., Murta, R. M.,... Souza, L. E. B. (2011). Zona de conforto térmico de ovinos da raça Santa Inês com base nas respostas fisiológicas. Revista Brasileira de Zootecnia, 40(8), 1807-1814. doi: 10.1590/S1516-35982011000800026

Fabino, R., Neto, Miyagi, E. S., Brainer, M. M. de A., Lima, L. G. F., \& Rebouças, G. F. (2018). Bem-estar na criação de ovinos em sistema intensivo. In D. A. C. Ferro, R. A. C. Ferro, \& B. P. A. Silva, Bem-estar para animais ruminantes (pp. 161-186). Goiânia: Kelps.

Ferreira, R. A., Estrada, L. H. C., Thiébaut, J. T. L., \& Granados, L. B. C. (2011). Avaliação do comportamento de ovinos Santa Inês em sistema silvipastoril no Norte Fluminense. 
Revista Ciência e Agrotecnologia, 35(2), 399-403. doi: 10.1590/S1413-70542011 000200023

Lima, C. B., Costa, T. G. P., Nascimento, T. L., \& Lima, D. M., Jr. (2014). Comportamento ingestivo e respostas fisiológicas de ovinos em pastejo no semiárido. Journal of Animal Behaviour and Biometerology, 2(1), 26-34. doi: 10.14269/2318-1265.v02 n01a05

Lima, L. R., \& Barbosa, J. A. D., Fo. (2013). Impacto do manejo pré-abate no bemestar de caprinos e ovinos. Journal oh Animal Behaviour and Biometerology, 1(2), 52-60. doi: 10.14269/2318-1265.v01 $\mathrm{n} 02 \mathrm{a} 04$

Luz, C. S. M., Fonseca, W. J. L., Barros, C. B., Jr., Sousa, G. G. T., Amorim, R. B., Silva, L. A.,... Santos, K. R. (2014). Estimativas de características termorreguladoras de ovinos em período seco e chuvoso criados na região do Vale do Gurguéia, Sul do Estado do Piauí. Acta Veterinaria Brasilica, 8(1), 19-24. doi: 10.21708/avb. 2014.8.1.3233

Macías-Cruz, U., Gastélum, M. A., AvendañoReyes, L., Correa-Calderón, A., Mellado, M., Chay-Canul, A. J., \& Arechiga, C. (2018). Variaciones en las respuestas termoregulatorias de ovejas de pelo durante los meses de verano en un clima desértico. Revista Mexicana de Ciencias Pecuarias, 9(4), 739-753. doi: 10.22319/ rmcp.v9i4.4527

Malafaia, P., Barbosa, J. D., Tokarnia, C. H., \& Oliveira, C. M. C. (2011). Distúrbios comportamentais em ruminantes não associados a doenças: origem, significado e importância. Pesquisa Veterinária
Brasileira, 31(9), 781-790, 2011. doi: 10.1590/S0100-736X2011000900010

Manno, M. C., Rodrigues, L. F. S., Lima, K. R. S., Carvalho, M. V. L., Rodrigues, S. S., Fo., Costa, G. L.,... Barreto, A. N. (2018). Behavioral aspects of Santa Inês sheep kept in pasture in a tropical rainforest climate. Ciência Rural, 49(1), 1-8. doi: 10. 1590/0103-8478cr20180033

Marques, J. A., Prado, I. N., Silva, P. A., Strada, E. S. O., Santana, A. L. A., Pinheiro, E. E. G.,... Santos, L. M. (2012). Comportamento ingestivo de diferentes categorias de ovinos Santa Inês em pastejo contínuo em Brachiaria decumbens. Revista de Ciências Exatas e da Terra e Ciências Agrárias, 7(1), 37-44.

Nobre, I. S., Souza, B. B., Marques, B. A. A., \& Batista, N. L. (2013). Efeito de diferentes níveis de concentrado e inclusão de gordura protegida na dieta sobre o desempenho produtivo e termorregulação de ovinos. Agropecuária Científica no Semiárido, 9(2), 14-20. doi: 10.30969/ acsa.v9i2.314

Oliveira, F. A., Turco, S. H. N., Broges, I., Clemente, C. A. A., Nascimento, T. V. C., \& Loiola, J. B., Fo. (2013). Parâmetros fisiológicos de ovinos Santa Inês submetidos a sombreamento com tela de polipropileno. Revista Brasileira de Engenharia Agrícola e Ambiental, 17(9), 1014-1019. doi: 10. 1590/S1415-43662013000900015

Rebouças, G. F., Silva, B. P. A., Rosanova, C., Fabiano, R., Neto, Lima, L. G. L., \& Figueiredo, C. B. (2018). Bem-estar de ovinos e caprinos criados á pasto. In D. A. C. Ferro, R. A. C. Ferro, \& B. P. A. Silva, Bemestar para animais ruminantes (pp. 135160). Goiânia: Kelps. 
Seixas, L., Melo, C. B., Tanure, C. B., Peripolli, V., \& Mcmanus, C. (2017). Heat tolerance in brazilian hair sheep. Asian-Australians Journal of Animal Science, 30(4), 593-601. doi: 10.5713/ajas.16.0191

Silanikove, N. (2000). Effects of heat stress on the welfare of extensively managed 1059 domestic ruminants. Livestock Production Science, 67(1-2), 1-18. doi: 10.1016/S03 01-6226(00)00162-7

Silva, T. P. D., Sousa, S. C., Jr., Santos, K. R., Marques, C. A. T., \& Torreão, J. N. C. (2013).
Características termorreguladoras e ganho de peso de cordeiros Santa Inês no sul do estado do Piauí no período de transição secaláguas. Revista Agrarian, 6(20), 198-204. doi: 10.30612/agrarian.v6i 20.2062

Thom, E. C. (1958). Cooling degrees - days air conditioning, heating, and ventilating. Transactions of the ASAE, 55(7), 65-72.

Voltolini, T. V. (2011). Produção de CAPRINOS e ovinos no Semiárido. Petrolina: EMBRAPA Semiárido. 